\title{
Religious Law in the Service of Human Rights?
}

\section{Developments in the Jurisdiction on Human Rights by Egypt's Supreme Constitutional Court in the 199 os}

\author{
Wiebke Greeff | ORCID: 0000-0001-5516-9987 \\ Officer for Young Academics with a focus on doctoral students and \\ international affairs, Department for Research and Transfer, \\ Carl von Ossietzky University Oldenburg, Oldenburg, Germany \\ w-greeff@t-online.de
}

\begin{abstract}
During the 199os, a period representing the peak of often novel interpretations in human rights litigation by the judges of the Egyptian Supreme Constitutional Court, Egypt's human rights performance was better than in other Islamic states sharing a commitment to the supremacy of Shari'a law. This article argues that there is a gap between the dogmatic assertion of the communal good life defined in traditional Islamic terms and the reality of governance usually at odds with these stipulations. The peculiar practice of the Egyptian Supreme Constitutional Court in the 199os highlighted two crucial, related questions: first, was it in principle possible to narrow that gap and align governmental action to rules derived from scripture? Second, does the highly fragmented and inconsistent character of classical Islamic law offer advantages in its adaptation to modernity? This article claims that the relative progress towards compliance with international human rights standards was due to progressive and strategically litigating judges, who used Islamic law opportunistically rather than dogmatically.
\end{abstract}

\section{Keywords}

Egypt - Supreme Constitutional Court - Islamic law - human rights law - human rights litigation - margins of judicial interpretation 
Islamic law represents an extreme case of a 'jurists' law'.

\section{Part I}

\section{Introduction}

For much of the twentieth century, the Arab world appeared immune to the pressures for democratisation that had been spreading in other parts of the world. ${ }^{2}$ The causes for this Arab exception have been multifaceted and include deeply unjust and inefficient political economies, unproductive and exclusionary labour markets, failing institutions, especially civic and educational, as well as a remarkable preponderance of religious thinking permeating all aspects of social and political life. ${ }^{3}$ As competing socio-economic models imported from the West and the East failed, Islam became seemingly the answer to all questions. ${ }^{4}$

Against this backdrop, Egypt presented in the 1990s an especially interesting example of this wider phenomenon. ${ }^{5}$ An authoritarian government nominally committed to socialism had responded to its rapidly declining legitimacy caused by lost wars and economic decline by promising religious salvation. Constitutional commitments to Islam, in particular the successively tightened requirement of anchoring all legislation and jurisprudence in Islamic law were deeply at odds with the structural logic of the modern administrative state the military was running. ${ }^{6}$ Initially dismissed as little more than populist rhetoric, the constitutional provisions requiring recourse to Islamic law were subsequently used by an activist, secular-trained judiciary to assert a greater degree of independence and expand legal limits on executive action. ${ }^{7}$ This

Schacht, An Introduction to Islamic Law, p. 5 .

2 See Fukuyama, Foreword, p. xv.

3 See The Editors, How the Arabs Compare, pp. 59-67.

4 See Salzman, When They Proclaim "Islam is the Answer" What is the Question?, pp. 129-152.

5 See Peters, The Islamization of Criminal Law, pp. 246-274.

6 See for a more in-depth discussion for instance: Lombardi, Islamic Law as a Source of Constitutional Law in Egypt, pp. 81-124.

7 Lombardi, Egypt's Supreme Constitutional Court, pp. 234-253. 
article presents key decisions ${ }^{8}$ by the Supreme Constitutional Court of Egypt, hereinafter SCC, in order to ascertain the extent to which international human rights standards are compatible with the Court's often novel ${ }^{9}$ interpretations of traditional Islamic jurisprudence, figh. $^{10}$

The Arab peoples emerged from world historical obscurity through the advent of a new religion that fuelled an ambitious political expansion. Despite its universal message, Islam reserved a special position to the Arab people, their language and their customs. The new religion was characterised by the extreme importance it attached to the observance of duties, at the relative expense of a spiritual message of salvation. Deciphering from the rather opaque but sacrosanct revealed sources which norms the faithful had to obey consequently became one, perhaps the chief object of intellectual and social concern. ${ }^{11}$

It is this particular insistence on obedience to concrete rules, rather than spirituality or ontological exposition, that accounts for the perplexing dominance of law in the religion of Islam. This centrality is stressed by Joseph Schacht, one of the chief Western students of the subjects in the opening lines to his classic textbook:

The sacred Law of Islam is an all-embracing body of religious duties, the totality of Allah's commands that regulate the life of every Muslim in all its aspects; it comprises on an equal footing ordinances regarding worship and ritual, as well as political and (in the narrow sense) legal rules. [...] Islamic law is the epitome of Islamic thought, the most typical manifestation of the Islamic way of life, the core and kernel of Islam itself. ${ }^{12}$

8 To not overstep the word limit of this Article, only the last Case No. 7 of Judicial Year 8, May 15, 1993 will be dealt with in a very detailed fashion for this Case provides the first Article 2 Case-decision of the scc during the early 199 os.

9 It should be noted, however, that the kind of utilitarian interpretation of traditional Islamic law relied upon by the Court had considerable precursors throughout Islamic history. For a discussion, see Lombardi, Islamic Law as a Source of Constitutional Law in Egypt, pp. 101-113.

10 See Moustafa, The Struggle for Constitutional Power, p. 7 et seq., p. go et seq.; Berger/ Sonneveld, Sharia and National Law in Egypt, pp. 51-88; Johansen, The Relationship Between the Constitution, the Sharîa and the Fiqh, pp. 881-896.

11 See here the comprehensive discussion in Johansen, The Muslim Figh as a Sacred Law, pp. $42-69$.

12 Schacht, An Introduction to Islamic Law, p. 1. 
Because the rules are all-encompassing, by definition perfect and immutable, while defying easy classification into functional categories, the absolute necessity of following them precisely and fully presented the believers with an enduring practical challenge: how to know precisely what God requires them to do?

The holy scripture, believed to be the actual word of God, while immutable and of unquestionable authority, offers only scant guidance, given the paucity of concrete rules contained and the considerable opaqueness of their wording. Consequently, following pre-Islamic Arab custom the example of the Prophet was deemed to offer much-needed elaboration and concretisation as a source of emulation. But while much more numerous and much easier to understand, this Sunna of the Prophet still remained less than exhaustive, offered great doubts about the reliability of the transmission and, again, considerable ambiguity about how individual acts and utterances were to be interpreted and applied to novel scenarios. The paramount importance of knowing precisely which obligations had to be fulfilled in order to avoid sanction in the afterlife thus presents believers with a problem common to all religions, but made especially acute given the relative dearth of spiritual content and the overwhelming importance of rules: how to build a coherent and practicable normative system from the rudiments of the revealed?

\section{3}

\section{Duality of State and Law}

Ever since the ascendancy of the West had become impossible to ignore in the late eighteenth century, ${ }^{13}$ Islamic civilisation and, especially, the traditional organisation of public space and executive power has become challenged by more effective, and therefore more prestigious, Western models. ${ }^{14}$ In the two centuries hence, virtually all Muslim societies have adopted, both through colonial imposition and voluntary choice, the Western bureaucratic state and its underlying model of rational, man-made law. ${ }^{15}$ In this uneasy process of transposing alien ideas of public life into the cultural soil of Islam, cherished notions of the good communal life came under attack, producing often violent reactions. ${ }^{16}$

13 Napoleon's invasion of Egypt in 1798 is a convenient marker, see for instance Cole, Napoleon's Egypt: Invading the Middle East.

14 See for instance Richmond, Egypt, 1798-1952; Fahmy, All the Pasha's Men.

15 See Agrama, Asking the Right Question, pp. 647-656.

16 Please refer - for an excellent introduction to this topic - to:Watt, Islamic Fundamentalism and Modernity. 
The idealised governmental model of Islam stems from its formative period in the urban communities of seventh century Arabia, where "a man called Muhammad came forward to proclaim a new religion. By the time of his death in II $/ 63_{2}$, he had left behind a small state and clear notions of justice, but with underdeveloped ideas of law and an even less developed judiciary."17 The fledgling nature of law and political community was rooted in the deliberate break with the political and legal past of Arab paganism, which led to the provisional adoption of a plurality of legal and governmental concepts. The latter were drawn from pre-Islamic Arab tradition and the custom and practices of conquered territories, given the imprimatur of religious compatibility. ${ }^{18}$

This process, given the extreme divergence of the sources from which it drew, led to a legal corpus "which was far from uniform."19 Islamic law did not treat all areas of law as equally relevant, of relevance for our present investigation for instance, it has "little specific to say [...] on matters of government administration or commerce." ${ }^{20}$ The result was a normative corpus characterised by an "inner duality" between legal subject-matters drawn from a wide variety of unrelated and often incompatible cultural cradles, and religious norms laid down in the two canonical revealed sources. This duality was compounded by the unsystematic mixing of ethical, ritual and legal norms so typical of sacred laws. ${ }^{21}$

Despite the paramount importance of knowing and obeying God's commands, the normative corpus emerging was not uniform but geographically and socially far more uneven than in either Jewish or Canon law. This has primarily to do with the dualism between state and religion. While the state was seen as the political expression of Islam, it, paradoxically, found it extremely difficult to establish an unchallenged interpretative authority over the creation and interpretation of law and religious dogma in the long term. Islam did not establish a recognised nomocracy comparable to a Church, as Schacht continues to highlight: Viewed over a longer period of time, Islamic law was not unconditionally and unambiguously supported by a sufficiently

17 Hallaq, The Origins and Evolution of Islamic Law, p. 8.

18 Hallaq offers in his many writings a highly, perhaps overly, sympathetic account, but he is correct to stress both the disjuncture between rulers and ruled, the limited ability of the ruling regime to control social practices and thus "the preservation and, indeed, enhancement of ancient forms of social and economic autonomy and local self-rule." Consequently, custom, morality and social ethics became "intertwined" and highly variable forms emerged. See Hallaq, Shari'a: Theory, Practice, Transformations, p. 159 et seq.

19 Schacht, An Introduction to Islamic Law, p. 2.

20 Martin, Creating an Islamic State, p. 4.

21 See Johansen, The Muslim Fiqh as a Sacred Law, pp. 42-53. 
organized power, consequently there $[\ldots$ did not $]$ develop [...] a real trial of strength; there merely existed a discordance between the sacred Law and the reality of actual practice of which the regulation framed by the state formed part, a gap more or less wide according to place and time, now and then on the point of being closed but continually reasserting itself. ${ }^{22}$

This gap between the dogmatic assertion of the communal good life defined in religious terms and the reality of governance usually at odds with these stipulations is therefore not new. But the peculiar practice of the scc highlighted two crucial, related questions: was it in principle possible to narrow that gap, i.e. was it possible to ground governmental action in rules derived from scripture? If that was the case, and the constitutional requirement enshrined (not only) in the Egyptian constitution points to the widespread aspiration that this was indeed possible, then a second, methodological question arose: Could the highly fragmented and inconsistent character of classical Islamic law actually offer advantages as it entered modernity? The deployment of different accounts, that is to say, traditional as well as modern approaches of figh reasoning by Egypt's judges during that peculiar window of opportunity in the 199 os helps to shed some light on that question.

\section{Divine Sources, Fiqh, Taqlid and the Four Orthodox Sunni} Legal Schools

In the classical era, legal interpretation was undertaken by a large number of private scholars keenly aware of the possibility of error. Against this backdrop, figh has thus been described as "processes of discourse among Islamic scholars [engaged in an] inquiry of the divine assessment of human acts."23 Because this discourse was conducted discretely of state power, the process was never subjected to a unifying hierarchy. Nevertheless, a hierarchy of competencies to interpret the sacrosanct sources and the attempt to curb and handle ambiguity and fragmentation in the law were realized by the establishment of the Four Sunni Orthodox Schools (madhhabs). ${ }^{24}$ In the third Islamic century, i.e. in the course of the gth century $\mathrm{CE}$

\footnotetext{
22 Schacht, An Introduction to Islamic Law, p. 2.

23 Lohlker, Islamisches Recht, p. 16.

24 The schools will here be referred to as either guilds or schools of orthodox legal reasoning or simply as guilds or schools.
} 
and subsequent centuries, with the emergence of legal schools formed around some of the most significant scholars, it came to be widely believed that all important questions of law had been dealt with and that the right of independent interpretation had been withdrawn for future generations. Henceforward, all were to accept the decisions of the early authorities - i.e., to exercise taqli $d^{25}$ toward them. This doctrine is usually expressed as "the closing of the gates of $i j t i h a d$ [independent reasoning]."26

Yet, as Schacht rightly underlines,

[n] owadays a position has been reached in which many Islamic scholars of a traditional background, without necessarily sharing all the opinions of the Modernists, recognize their efforts as legitimate and act, in a way, as their advisors; the uncompromising demand of taqlid, the unquestioning acceptance of the traditional doctrine of one school of law, in particular, have lost much ground. ${ }^{27}$ (italics added)

While the Qur'an is "the ultimate, dispositive source of law in the Sharia, its finite text $[. .$.$] cannot possibly answer directly every legal question that arises$ after its revelation and recording." The need for flexibility, adaptability and not least practicability thus led to the recognition of "the Sunnah of the Prophet Muhammad as an alternative [primary] source of law to the Qur'an."28 Despite this enormous enlargement of divine source material, applicable law still relied overwhelmingly on human interpretation, which yielded extremely divergent legal rules: "The claim that all Islamic law would be divine must [therefore] be largely relativized."29 Put differently, "there is not one, firmly established Islamic law." ${ }^{30}$ Hence, the importance of the question who is in charge of exegesis and application of the law.

Beyond ijma (consensus) and qiyas (analogy) there are another five lawfinding-methods within the scope of figh. ${ }^{31}$ They tend to be more contentious among scholars of Islamic law when compared to ijma and qiyas because they

25 The method of taqlid can literally be translated from Arabic as imitation and/or emulation.

26 Zaidam, Taqlìd, Islamic Law.

27 Schacht, An Introduction to Islamic Law, p. 102.

28 Burns, Introduction to Islamic Law, p. 26.

29 Rohe, Das islamische Recht, p. 10.

30 Rohe, Das islamische Recht, p. 16.

31 Figh is identified best by the term of knowledge, and, to be precise, knowledge about how to extract the meaning of the primary sources of Islamic law. In accordance with Ibn Chaldun (14th century) and Rohe (2013, p. 10) figh, or Islamic jurisprudence, will here be understood as the knowledge of every qualified Muslim capable to find and apply the divine provisions of the primary sources. 
are deemed tainted by human error. But as figh has rightly been described as a "jurists' law",32 it is ultimately only through these subsidiary methods that concrete legal norms can be derived. Ijtihad, the most important for the purposes of this article will here be defined as striving for a correct legal conclusion through individual, and thus subjective and independent reasoning. ${ }^{33}$ Put differently, ijtihad can be characterized as the "process of identifying rulings in the text of the Qur'an and hadith literature, and, where necessary, supplementing them with new rulings that had been logically extrapolated from the scriptural rulings." 34 In other words, ijtihad "was often described as a process of deriving figh from four sources: Qur'an [and Sunna], hadith literature, consensus (ijma), and juristic logic (qiyas) [or analogy]. While accurate, this description does not, by itself, make clear how the process works." ${ }^{35}$ When discussing case law, I will thus discuss in more detail which sources (or interpretations of the divine sources) were considered by whom as sources that could help to provide knowledge about the underlying goals and principles behind the sacred texts.

The hadiths will here be defined as "reports describing events in the life of the Prophet and his companions." ${ }^{36}$ As we will learn below in the context of 199os Egypt, ijtihad and a re-interpretation of ijtihad (so-called utilitarian neoijtihad) did facilitate "a high level of flexibility in order to adapt Islamic law to constantly changing living conditions." ${ }^{37}$ The Arabic term for "public interest", maslahah mursalah, in turn "allows for the consideration of public benefit as a guide for rulemaking and adjudicating disputes." 38

Fragmentation in Islamic law and the query for competencies in regard to exegesis can explain the abundance of terms related to the Four Orthodox Sunni Legal Schools, its scholars, titles and methods of figh in order to extract God's command from the divine primary sources. The heavy segmentation of law combined with the ambivalence of many parts of the scripture - as one crucial feature of Islamic law - was tried to be kept in check through the formation of the Four Orthodox Sunni Legal Schools, ${ }^{39}$ which ensured a high degree of conformity within each. Accordingly, the notion of madhhab must not be unnoticed here as it defines a "legal opinion or juristic principle" 40 as

\footnotetext{
32 Schacht, An Introduction to Islamic Law, p. 5.

33 See Burns, Introduction to Islamic Law, p. 31.

34 Lombardi, State Law as Islamic Law in Modern Egypt, p. 40.

35 Lombardi, State Law as Islamic Law in Modern Egypt, p. 21.

36 Lombardi, State Law as Islamic Law in Modern Egypt, p. 23.

37 Rohe, Das islamische Recht, p. 19.

38 Burns, Introduction to Islamic Law, p. 32.

39 See Schacht, The Schools of Law and Later Developments of Jurisprudence, pp. 57-84.

40 Hallaq, An Introduction to Islamic Law, p. 175.
} 
adopted by one of the Four Orthodox Schools or Guilds respectively. Yet, this relative stability and continuity provided by the orthodoxy within each of the four guilds remained always marked by the fragile "balance between the acceptance of enormous plurality of legal opinions and the need for a functioning jurisprudence." ${ }^{41}$

\section{$5 \quad$ The Four Orthodox Sunni Legal Schools (Guilds)}

As Hallaq notes, in the traditional period, the "four doctrinal schools that survived in Sunni Islam are said to have been founded by Abu Hanifa (d. 767), Malik b. Anas (d. 795), Ibn Idris al-Shaf'i (d. 820) and Ahmad b. Hanbal (d. 855)."42 According to the surnames of their founders, these schools have become known and established under the Hanafi, Maliki, Sha'fi and Hanbali schools or guilds of orthodox legal reasoning. Considering the legal scholars entitled to interpret the divine sources, different outreaches of knowledge and education have designated the reach of according competencies related to the interpretation of Islamic law. At the end of that scale of legal expertise, the authority to extract God's commands from divine sources has, since the death of the Prophet, been traditionally entitled to those jurists endowed with the privilege to conduct ijtihad.

Again, the latter concept defines the legal methods of interpretation and reasoning by which a mujtahid, at the top of this hierarchy or at the end (or top) of a scale of legal knowledge and education, derives new law on the basis of an in-depth interpretation of "the Qur'an, the Sunna and/or consensus." During the latter half of the 19th century, early legal reform movements incrementally began to gain momentum in the whole North African and Middle Eastern region (MENA). And by means of these reforms, Western legal impact and new ideas, addressing the question of how to reform Islamic legal systems, began to increase significantly. ${ }^{44}$ Against this backdrop, it is important to understand significant terms and the changes related to their meaning over time. This holds especially for 1) concepts pertaining to figh, and 2) notions such as Islamic scholars, judges and/or jurists. This is important because the

\footnotetext{
41 Bauer, Die Kultur der Ambiguität, p. 180.

42 Hallaq, An Introduction to Islamic Law, p. 175.

43 Hallaq, An Introduction to Islamic Law, p. 175.

44 See for a more detailed description of these processes not only with regard to Egypt but in consideration of the whole region of Middle East and North Africa (MENA) for example: Thompson, Justice Interrupted; Brown, Retrospective: Law and Imperialism, pp. 103-125; Arjomand, Constitutions and the Struggle for Political Order, pp. 39-82.
} 
meaning of these crucial terms and concepts did - of course - change over time and the notion of a jurist, for instance, must therefore be understood in its historical context in order to not confound underlying meanings.

In this article, I claim that SCC's judges were successful in extending their own competencies in litigating cases involving Islamic law. Moreover, I argue that they were successful in their strategies precisely because they were savvy enough to know and understand all of the relevant and often competing meanings behind crucial terms and concepts very well. In turn, this knowledge allowed the secularly-trained judges to estimate the extent to which Egyptians were either sceptical or receptive to the following two powerful movements in the context of legal and judicial reform efforts. First, international human rights law and activism, and second, more or less progressive precursors to the scC's own liberal account to interpret Shari'a law. As Gabr ${ }^{45}$ rightly notes in this context, precursors in terms of earlier reform efforts just as the 1980 constitutional amendment "initiated a welcome and vigorous debate about the balance to be achieved between the respect to be accorded to Egypt's customs and traditions whilst also acknowledging contemporary attitudes and international influences. This debate has extended far beyond the court-room reaching both the public and private sphere." 46

In terms of terminology, Hallaq ${ }^{47}$ notes that a jurist was traditionally considered a legist "who achieved a remarkably high level of legal knowledge." Thus, in the context of the classical era, every jurist was also a legist, but "not every legist or even judge was a jurist." It is important to note that whenever I refer to late 2oth century Egyptian higher jurists or ScC's judges, these judges received a secular training. Again, terms and concepts of 199os Egypt differ in their meaning when compared to the use of these terms and concepts related to classical terminology. As Hallaq underlines, a faqih (pl. fuqaha) can be considered "an expert in the law; an 'alim (pl. ulama)." ${ }^{8}$ Thus, the ulama will here be referred to as either the legally-learned, that is to say the legists in this technical sense, implying traditional and/or secular legal training and a legal degree, or as "representatives of the Shari'a".99 In any way, ulama here designates a term that explicitly includes Egypt's judges of the Scc despite but also because of their far more liberal reading of the Shari'a when compared to the classical era. In brief, I argue that irrespective of traditional or liberal accounts to

See Gabr, The interpretation of Article 2 of the Constitution, pp. 217-227.

Gabr, The interpretation of Article 2 of the Constitution, p. 218.

Hallaq, An Introduction to Islamic Law, p. 174 et seq.

48 Hallaq, An Introduction to Islamic Law, p. 173.

49 Schacht, An Introduction to Islamic Law, p. 84. 
interpret Sharia law, the ulama will here always be identified with those whose binding legal interpretations and rulings ensue from the direct engagement with the Sharia.

Throughout the last quarter of the 2oth century, the SCC increased its expertise and consolidated acceptance among different groups of Egyptians towards a new reading of Shari'a law. Historically and against this backdrop, it might be useful to know that before the promulgation of a new law, which was released in Al-Ahram on September 22nd in 1955, one could hardly claim that Egypt had ever provided even rudimentarily for a functioning jurisprudence when defined as the absence of overlapping and unclear jurisdiction.

Rather, with regard to a uniform jurisprudence, implying a clear division of competencies on the part of different state and various confessional courts, jurisprudence in pre-1955 suffered heavily from a highly chaotic and "abnormal situation".50 It was only in 1955, when, in a surprise move on September 21st, increasing trends of secularism and nationalism had caused the government to enact a new law which abolished all shari'a (Muslim religious) and milliyah (Christian ecclesiastical and Jewish rabbinical) courts, that the sheer unbearable situation of overlapping jurisdiction was mitigated by the new law. ${ }^{51}$ Article 1 of the law of September 21, reads that "Sharia and milliyah courts shall, as from January 1, 1956, be abolished. All cases pending before the said courts by December 31, 1955 shall be transferred to the national courts." 52 (italics added)

However, the government was reluctant to abolish "entirely the centuriesold institution of personal status and did not altogether secularize and unify family law." ${ }^{53}$ Although all confessional courts were abolished by the new law of September 21, 1955, the law

does not affect the substantive shari'a law and the various laws and customs applicable to members of the religious communities in Egypt. The new law expressly provides that, in exercising their newly required jurisdiction in matters of personal status, the civil courts shall apply the various religious laws of the litigants which has been formerly applied by the shari'a and milliyah tribunals. ${ }^{54}$ (italics added)

$5^{\circ}$ Safran, Abolition of the Shar 'i Courts in Egypt, p. 23.

$5^{1}$ See Sfeir, The Abolition of Confessional Jurisdiction in Egypt, pp. 248-256.

$5^{2}$ Sfeir, The Abolition of Confessional Jurisdiction in Egypt, p. 248.

53 Sfeir, The Abolition of Confessional Jurisdiction in Egypt, p. 248.

54 Sfeir, The Abolition of Confessional Jurisdiction in Egypt, p. 248. 
Moreover, the Egyptian law of September 21, 1955 provides for Muslim qadis (judges of the former sharia courts) "to sit on the bench of the civil courts when these latter hear cases of personal status." ${ }^{55}$ Hence, since the promulgation of that law, judicial cooperation between secular state judges and qadis in specific matters was common and facilitated, among other factors, 199os secularly-trained judges to gradually gain acceptance among more traditionally-trained and conservative Islamic judges to litigate the so-called Article $2^{56}$ cases, involving the interpretation of Shari'a law, explicitly including matters of personal status and thus Islamic family law.

During the decade discussed with preference here, the 199os, scc's judges came to establish enough standing to interpret - as secular representatives of the Sharia, and thus, as secular fuqaha or secular ulama - the divine sources in a far more liberal way than ever before in Egyptian modern history. In this context, it cannot be overstressed that many Egyptians at the time did accept the secularly-trained judges to represent the Sharia even though their exegesis differed clearly from traditional accounts of interpreting the sacrosanct sources. While the very definition of a traditionalist (legal scholar) is tantamount to "one who studies and transmits the hadith",57 it does not come as a surprise that, albeit accepted for their new interpretations of divine law, the SCC was confronted with the criticism that it "must pay more attention to the hadith literature and show more deference to traditional interpretations of [the] law." 58 As indicated above, the so-called hadith are the "Prophetic traditions or reports of what the Prophet had said, done or tacitly approved with regard to a particular matter. The term is both singular and plural."59 Even though the sCC has, probably for strategic reasons, "chosen not to elaborate every aspect of its interpretive method"60 the most plausible reason of the scc not to reference the hadiths more extensively might be that judges had doubts about the

Sfeir, The Abolition of Confessional Jurisdiction in Egypt, p. 249 .

56 While Art. 2 of Egypt's constitution of 2014 and of the 1980 amendment of Egypt's constitution of 1971 both read that "The principles of Islamic Sharia are the principle source of legislation" (italics added), the 1971 constitution reads that "The principles of Islamic Sharia are $a$ principle source of legislation" (italics added). Notably, the amendments of Egypt's constitution of 1971 in 198 o enhanced the commitment to Islamic law "by a single word: the principles of the Islamic shari'a were now to be "the" rather than "a" primary source of law (Article 2)"; see Brown, Constitutions in a Nonconstitutional World, p. 84; Constitute Project, Egypt's Constitution of 2014.

57 Hallaq, An Introduction to Islamic Law, p. 173.

$5^{8}$ Lombardi, State Law as Islamic Law in Modern Egypt, p. 259.

59 Hallaq, An Introduction to Islamic Law, p. 173.

6o Lombardi, State Law as Islamic Law in Modern Egypt, p. 273. 
hadiths' authenticity both in terms of their transmission but also as regards the aspect of clarity in terms of their meaning(s).

\section{$6 \quad$ Talfiq and the Decline of the Four Orthodox Guilds}

While traditional theories reserved the difficult task to extract God's commands to the classically-trained ulama, modernists and even some of the neo-traditionalists argued that the "new" classically-trained ulama should rather play an advisory role. Due to the fact that many Egyptians - at least temporarily - embraced legal positivism after the decline of the four guilds during the 19th century, ${ }^{61}$ advise was urgently needed with regard to the question how to conciliate state law, involving secular codes, with Islamic primary sources.

With the beginning of the 2oth century at the latest, a vivid discussion emerged among scholars and legal experts addressing the issue if jurists should not be (more) willing to adapt new methods of Islamic legal reasoning such as talfiq. Literally to be translated by the notions of "patching, fabricating, amalgamating or concocting" talfiq describes "a reforming method of bringing together different parts of a doctrine/ opinion from various schools so as to create, on a specific point of law, a modernized doctrine." ${ }^{2}$ Members of the ulama, who are to derive law through the concept of talfiq, many neo-traditionalists argued, should draft national legal codes in accordance with Islamic rules that had, however, to be applicable to modern times and strengthen Muslim society's welfare as opposed to the ruler's welfare. ${ }^{63}$

\section{Part II}

\section{Methodological Creativity}

Tendencies strengthening the flexibility inherent in the methods of figh started to gain momentum when the Egyptian elite was successful in convincing the Egyptian government that it should "promulgate legal codes whose rules were

\footnotetext{
61 See Lombardi, State Law as Islamic Law in Modern Egypt, p. 78.

62 Hallaq, An Introduction to Islamic Law, p. 177.

63 As we will see with regard to the discussion of case law and the scc's reasoning, the aspect of public welfare plays a crucial role in nearly all of the court's rulings during the 199os.
} 
taken from European models." ${ }^{64}$ In that climate - during the last quarter of the 19th century - some of the more progressive modernist Islamic legal thinkers would even argue that not just the ulama, but "any educated Muslim has the ability to interpret Islamic law."65 The Egyptian scc seems to have reinterpreted this account throughout the 199os with a view to upgrading and reinforcing its own authorities. Rejecting the idea that allowance to interpret Islamic law could be endowed to any educated Muslim, the SCC rather devised itself as the institution with absolute predominance in terms of exegesis.

With the aid of progressive, secularly-trained and certainly well-educated sCC jurists, the prerogative of interpreting and thus representing Sharia had been shifted, however incrementally, from the traditional ulama and the four guilds to the scc.

The reluctance of the Court to be more open to explain its concrete method to identify which of the scriptural texts it considered "absolutely certain to be authentic" may indeed "reflect the Court's concern that it has gone too far ahead of Egyptian society." 66 Yet, by the mid-19oos, scc's judges were sufficiently confident to act upon their assumption that those in charge of constitutional review were most naturally those entitled to interpret Sharia and thus to decide which of the precedent accounts they would accept as trustworthy, reliable sources. During the period indicated, Egypt's senior judiciary relied upon arguments built on notions of classical Islamic law, such as ijtihad, but also on modernist theories of Islamic law to further its liberal agenda. As the discussion of case law will reveal, this liberal agenda was broadly in conformity with contemporary international human rights standards and especially women's equal rights.

The SCC was very well aware that due to anti-colonial resentments predominant during the first half of the twentieth century, many thinkers who articulated modernist Islamic legal accounts during this period were eager to stress "that their theories grew organically out of classical Islamic theory. [...] As a result, Egyptian modernist legal theories often 'sound' classical at first." ${ }^{67}$ Yet, despite reference to known terms and concepts, classical, new and especially more modern versions of Islamic legal accounts often do not imply the same underlying assumptions and consequences at all. Rather, they differ quite significantly with regard to their suggested outcome. Yet, the main challenge characteristic for Islamic law remains and is due to its fragmentary

64 Lombardi, State Law as Islamic Law in Modern Egypt, p. 78.

65 Lombardi, State Law as Islamic Law in Modern Egypt, p. 83.

66 Lombardi, State Law as Islamic Law in Modern Egypt, p. 273.

67 Lombardi, State Law as Islamic Law in Modern Egypt, p. 79. 
and highly diverse nature. Because the divine sources do not provide enough precise legal instructions, interpretation has always played an enormous role. Consequently, the question who should be authorized to extract the law from these sacrosanct, but opaque primary sources and which sources count as authentic and clear with regard to their meaning, has always been a question of power. (4January 1992)

Conflicts between Sharia and international human rights norms must not be underestimated. Incompatibilities have been emphasized by many scholars, especially considering Islamic provisions regarding: (a) criminal justice, (b) freedom of religion and the treatment of religious minorities and (c) women's legal status. ${ }^{68}$ Given the evidently differential legal treatment accorded to men and women, as well as to Muslims and Non-Muslims in Islamic law, the simultaneous constitutional commitments to equality (in Article 40 of the 1971 Constitution and Article 53 of the 2014 Constitution) and the supremacy of Islamic law (in Article 2 of each) presents ample scope for tension. The practical question has been whether conservative, textualist interpretations of the classical normative canon would increase this tension, or whether a flexible, teleological, interpretation by liberal and independent judges could alleviate it. Interestingly, the discussion of Case No 7, Judicial Year 8 (May 15, 1993), printed in $s c c$, vol $\mathrm{v}$, part 2, to be discussed in detail below, suggests that a modern textualist approach on the part of the new, secular ulama is not only apt to decrease this tension, but suggests further that the stress on the need to enact state law that promotes social benefits, equal rights and society's welfare and thus, in modern terms, human rights law, can be drawn from certain Sharia verses themselves (see paragraphs XIII and XIV).

The judges of the SCC were savvy by claiming that a dual commitment to the rule of law and Islamic legal principles would mutually reinforce each other and inform all other constitutional principles. For a period of approximately 10 years, such liberal judges were able to creatively use the methodological flexibility characteristic of figh to further a compliance with basic human rights standards. In the early 199os, scC's judges identified in the text of the 1971 Constitution two overarching principles that according to the Court's majority should inform the reading of all other constitutional provisions. First, Article 64

68 See Abiad, Sharia, Muslim States and International Rights Treaty Obligations, p. 21. 
guarantees the rule of law by making it "the basis of state rule." Article 65 further stipulates unequivocally that the state is "subject to the rule of law"69 and asserts the necessity of judicial independence to protect rights and liberties. These provisions, the Court's majority argued, required it to incorporate international human rights principles into Egyptian constitutional law. ${ }^{70}$

Second, it argued that Article 2 posited the complementary overarching notion that all law should conform to Islamic legal principles. In the Court's opinion, these two notions were mutually reinforcing. In Case No 22, Judicial Year $8,{ }^{71}$ the Court held on 4 January 1992

that the human rights clauses of the constitution had to be interpreted in accordance with those norms generally recognised and applied by democratic states, including international standards applicable in those states. The Court also declared that the legislature had to take international human rights treaty commitments of the State into account when passing legislation. ${ }^{72}$

The Court's reasoning was remarkable in that the 1971 Constitution does not clearly indicate at what level of the internal legal hierarchy the body of human rights treaty law would take effect. Furthermore, "[a]ccording to the formal theory of lex posterior derogat priori, subsequent legislation could in principle take precedence over the provisions of the treaties." ${ }^{73}$ Thus, it was largely due to the reasoning of the judges in this key decision of Case No 22, Judicial Year 8, that the SCC set a milestone to ensure that treaty law of a human rights character had been given "a special status as a constitutional principle."74 In a whole series of widely noticed decisions, the SCC interpreted constitutional and Islamic legal principles in a creative manner to support its liberal views with respect to economic, civil and political rights as well as equal protection clauses, often with a view to fostering women's equal rights. ${ }^{75}$

\footnotetext{
69 Boyle, Human Rights in Egypt, p. 9 o.

70 See Boyle, Human Rights in Egypt, p. 9o.

71 For further information on this case, which concerned the dismissal of an officer from the Egyptian army for alleged cowardice in action in Yemen, see Boyle, Human Rights in Egypt, p. 9 o.

72 Boyle, Human Rights in Egypt, p. 90.

73 Boyle, Human Rights in Egypt, p. 90.

74 Boyle, Human Rights in Egypt, p. 9o.

75 See Lombardi, Egypt's Supreme Constitutional Court, p. 244.
} 


\section{Underlying Strategies of an Under-Explained, Embryonic New Liberal Theory}

Before I refer to a seminal case substantiating the accuracy of Lombardi's claim that the scc "has created an embryonic new theory of Islamic law - one which represents a pastiche of influential modernist Islamic legal theories",76 I need to discuss which modern accounts scc judges referenced and combined to develop their own liberal account. The following discussion heavily relies on the arguments developed in Lombardi's book (2006) for the following two reasons. First, this book provides the first book-length-study addressing especially, but not exclusively, the Court's appraisal with reference to the so-called Article 2 cases. Second, Lombardi translated key cases from Arabic to English. Needless to stress, this is highly beneficial for the purposes of this article. It allows me to elaborate the reasoning of the judges and to draw my conclusions directly from an analysis of their processes of conducting modern ijtihad to contrive their opinions and, finally, their much-debated rulings. This approach focusing on Scc judges' reasoning will here be exemplified with regard to Case No. 7 Judicial Year 8, issued on May 15, 1993, which constitutes the first of the so-called Article 2 cases and will be discussed in a very detailed manner further below.

When the new 1971 Egyptian Constitution was promulgated, "Article 2 provided that the principles of the Islamic sharia are $a$ chief source of Egyptian legislation." ${ }^{77}$ Nine years later, when the constitution was amended, the "commitment to Islamic law was enhanced by a single word: the principles of the Islamic shari'a were now to be 'the' rather than 'a' primary source of law."78 With a seminal ruling in 1985, the scc held that Article 2 as amended in 1980 "required that all legislation enacted after the amendment be reviewed for consistency 'with the principles of the Islamic sharia."79 (italics added)

\section{Re-conceptions of the Doctrine of siyasa shari'yya}

According to classical Sunni legal theories and in order to avoid an extreme fragmentation of Islamic law, it was the duty of qualified jurists to elucidate God's law in accordance with one of the Four Sunni Guilds (madhhabs) to one

\footnotetext{
$76 \quad$ Lombardi, State Law as Islamic Law in Modern Egypt, p. 268.

77 Lombardi, State Law as Islamic Law in Modern Egypt, p. 1.

78 Brown, Constitutions in a Nonconstitutional World, p. 84.

79 Lombardi, State Law as Islamic Law in Modern Egypt, p. 2.
} 
of which each jurist belonged. As indicated above, these madhhabs are the Hanafi, Maliki, Shafi'i and Hanbali schools whose relevance in the context of classical Islamic legal interpretation cannot be overestimated. Traditional, or here also referred to as classical Islamic law, was "carried out exclusively by jurists trained in and licensed by the Sunni law guilds [so that] classical jurists were bound by the traditional methodological and substantive legal doctrines of their guilds." ${ }^{\text {80 }}$ (italics added)

The liberal theory of the SCC differs from the classical legal theories just as it differs from the so-called neo-traditional accounts especially with regard to one crucial point. While the latter two approaches attribute the unique ability to interpret Islamic law to the ulama, that is the religiously-trained scholars of Islamic law, the theory of the Scc explicitly rejects that restriction. However, it must be emphasized that neo-traditional theories differ - in turn - from classical legal theories in that jurists who qualify as ulama in the modern world "have very different training and institutional affiliation than the classical jurists, and use slightly different methods of interpreting shari'a." ${ }^{81}$ It is likely that the surprisingly broad, albeit fragile, acceptance for the SCC's liberal account - even by different branches of Islamists trained at the training ground for Islamic law in Egypt, al-Azhar - is due to the enormous weakening of the Egyptian branches of the Sunni guilds.

By the middle of the twentieth century, successful students of Islamic law at al-Azhar no longer received from a jurist a "license" authorizing them to issue opinions of that jurist's particular guild. Instead they received a government-issued diploma in Islamic legal studies from al-Azhar. They were not indoctrinated into a system that assumed they should follow a particular guild's method of interpreting Islamic law. In the twentieth century, ulama thus came to embrace methods of interpreting Islamic law or of drafting Islamic legislation that did not require an interpreter to interpret Islamic law in light of any particular guild of law (italics added)..$^{82}$

The SCC certainly profited from these changes related to the destruction of the prerogative of interpretation on the part of the guilds and the classicallytrained ulama. Furthermore, under these conditions, criticism and suspicion on the part of conservatives may not reasonably be constrained to state

8o Lombardi, State Law as Islamic Law in Modern Egypt, p. 8o.

81 Lombardi, State Law as Islamic Law in Modern Egypt, p. 81.

82 Lombardi, State Law as Islamic Law in Modern Egypt, p. 81. 
employees like scc's judges, but may expand to the leading modern ulama as they receive state-run training nowadays, too. Moreover, it is significant to underline that not only the scc's liberal account but also many other modern Islamic theories reject the traditional ulama's unique authority to interpret Islamic law. Thus, it is hard to see why an interpretation controlled by SCC judges would be inherently less "Islamic" and automatically more progressive than one designed by members of the modern ulama.

While the neo-traditionalist assumption of the traditional ulama's prerogative of interpretation has been rejected not only by the SCC, but also by other modernist Islamic legal thinkers, modernist accounts and neo-traditional theories share, nevertheless, one common conjecture. They both accept "the basic premise of the classical theory of siyasa shari'yya." ${ }^{\prime 3}$ To be translated literally by statecraft in accordance with sharia law, its basic assumptions can be summarized as follows: under the aspect "of siyasa shari'yya a ruler can require his courts to find their rules of decision in a body of $f i g h$. (A jurist's figh will always be consistent with the universal rulings of the shari'a and will, presumably be beneficial for society.)" 84

As the discussion of case law will demonstrate, the interpretation of what is beneficial for society lies, of course, in the eye of the beholder. During the 199os, the SCC has referenced the concept of benefits for society as a whole as one crucial and universal principle of Sharia quite extensively, and this not without a reason. The Court could be assured that reference to the benefits for society as a goal extracted directly from Sharia law was not likely to be overwhelmingly questioned. This is partly due to the fact that already during the first part of the 2oth century, Egypt witnessed the rise of powerful Islamist opposition movements embracing various re-conceptions of the doctrine of siyasa shari'yya. As a reaction to the rather cautious resistance to the process of codification and secularization of Egyptian law that had begun during the last quarter of the 19th century, various Islamists groups began to argue that "Egyptian law needed to be consistent with the universally applicable rulings of the shari'a and the goals of the shari'a". However, these movements were also inclined towards "new methods of interpretation to identify and apply these rulings and goals." 85

83 Lombardi, State Law as Islamic Law in Modern Egypt, p. 79.

84 Lombardi, State Law as Islamic Law in Modern Egypt, p. 5o.

85 Lombardi, State Law as Islamic Law in Modern Egypt, p. 8o. 
Case No 7, Judicial Year 8 can be considered the first substantive interpretation of the scc's Article 2 cases and concerned the rights of a divorced woman and her children. It was the very "first case in which the scc had to decide a constitutional challenge that involved a challenge under Article 2 alone, rather than Article 2 and other provisions of the Constitution as well." 86

The case was brought before the Ordinary Court in 1985 by a divorced mother endowed with the guardianship of the children of the marriage. The mother claimed for

the right to sole occupation of the former marital home in accordance with the first paragraph of Article 20 of Personal Status Law No 25 of 1929 as amended by Law No 100 of 1985 . This legislation provided that, although ordinarily the guardianship rights of a women terminated when the boy child reached the age of ten and the girl child twelve, these periods could be extended by the court until the age of fifteen in the case of the former and until marriage in the case of the latter. ${ }^{87}$

Moreover, the mother also claimed entitlement to the mut'a (or motaa), that is to say she claimed entitlement to alimony under Article 18 of the same law.

While Article 20 granted special child custody rights to women who had been divorced by their husbands without cause, Article 18

permitted a judge to order a man to pay his divorced wife a sum of money analogous to an alimony payment [...] 'mut'a'. Applying these provisions, the judge awarded the divorced mother permanent custody of the children of the marriage, and he ordered the husband to pay his ex-wife a mut'a payment. Upset by the terms of the divorce, the father challenged Article 20 and 18 as unconstitutional - arguing that they were inconsistent with Islamic law and thus impermissible under Article $2 .{ }^{88}$

Therefore, the claim was transferred to the ScC which "derives its judicial status and competencies from Articles 174-178 of the 1971 Constitution." 89

86 Lombardi, State Law as Islamic Law in Modern Egypt, p. 202.

87 Gabr, The interpretation of Article 2 of the Constitution, p. 220 et seq.

88 Lombardi, State Law as Islamic Law in Modern Egypt, p. 202.

89 Most importantly, Article 175 reads "The Supreme Constitutional Court alone shall undertake the judicial control in respect of the constitutionality of the laws and regulations, and shall undertake the interpretation of the legislative texts in the manner prescribed by law. The law shall determine the other competencies of the court, and regulate the 
While the classical jurists of all Sunni legal guilds agreed that there was a period during which each child needed nurturing and care that only a mother could give, the so-called hadana, and that older children needed the strict moral guidance of the father and the father's family, the so-called wilayat al tarbiyya, they disagreed on the specific terms of these two periods and especially they disagreed on their precise duration.

"In pre-modern Egypt, the courts applied an un-codified version of Islamic law [...] and, when seeking figh rulings, parties before the court were allowed to decide for themselves which guild's interpretation of Islamic law should apply to their case. ${ }^{\prime 90}$ In 1929 the Code of Personal Status, however, changed Egyptian law in that henceforth, the new Code would require the Courts

to apply the Hanafi rules in most areas of family law. Accordingly, the 1929 Egyptian Code of Personal Status in its original form followed the Hanafi rule and allowed the judge, if 'the interest of the child requires it', to extend the mother's custody (hadana) over her son until he was ten and her daughter until she was twelve, at which point the period of wilayat al tarbiyya began and custody automatically reverted to the father. ${ }^{91}$

But as Hanafi rules were largely considered inconsistent with the values of colonial powers, in 1979 amendments to personal status law were enacted, struck down and later re-enacted as part of Law 100 of 1985 .

Hence, after 1985, Article 20 of Law 100 of 1985

provided that a divorced woman automatically received custody of her male children of her marriage up to the age of ten and custody of her female children up to the age of twelve. If the judge believed it was in the best interest of the son, he or she could extend the mother's right of custody over that son until he reached the age of fifteen. If the judge thought it was in the best interest of a daughter, he [or she] could extend the mother's custody of that daughter up to the consummation of her marriage and at the judge's discretion, the mother could be awarded child support. ${ }^{92}$

procedures to be followed before it." See for more details for instance: El-Morr/Nossier/ Sherif, The Supreme Constitutional Court and its Role in the Egyptian Judicial System, p. 37.

90 Lombardi, State Law as Islamic Law in Modern Egypt, p. 204.

91 Egyptian Code of Personal Status (March 10, 1929), Article 20 as cited in: Lombardi, State Law as Islamic Law in Modern Egypt, p. 204.

92 Case No. 7, Judicial Year 8 (May 15, 1993), p. 285, as cited in: Lombardi, State Law as Islamic Law in Modern Egypt, p. 205. 
In Case No. 7 , the appellant father claimed

that from 1929 until 1979, Egyptian personal status law had followed Hanafi doctrine. Accordingly, he argued, when the Egyptian legislature drafted Article 2 to require Egyptian law to conform to the principles of the Sharia, it must have intended that Egyptian law transform to the traditional Hanafi interpretation of the Sharia. Because the personal status law, as amended, was inconsistent with Hanafi law, the father argued, the new provisions should be deemed void, and the Egyptian courts should apply the rule that would have applied if the amendment had never been enacted. The SCC rejected the father's initial contention that Article 2 required Egyptian legislation to be consistent with Hanafi interpretations of Islamic law. Going further, it declared that modern Muslims were not bound by the classical juristic tradition. Accordingly, under certain circumstances, Islamic law permitted rulers to promulgate laws that were inconsistent with rulings accepted by all Sunni jurists of the past. At the broadest level, the Court vigorously asserted the modernist position that modern Muslims were not bound by classical interpretations and rejected the neo-traditional idea that contemporary interpretation should be performed by scholars with classical training. ${ }^{93}$

Therefore, the father's

claim that the first paragraph of Article 20 was unconstitutional was not upheld. In reaching this decision the Court ruled that the true meaning of the amended Article 2 of the Constitution was that legislation should not contradict those Islamic Shari'a principles that were derived from definite sources and which represented the religious foundations of Egyptian society. ${ }^{94}$ (italics added)

Consequently, the Court argued, these definite principles were not subject to discretionary interpretation but rather "existed for perpetuity. The Court's competence merely extended to ensuring that they were abided by and that any legal norms which contravened them were deemed invalid." 95

In this context, the SCC argued that the child's welfare must be considered one among the universal principles and thus also one among the definite rules

93 Lombardi, State Law as Islamic Law in Modern Egypt, p. 205 et seq.

94 Gabr, The interpretation of Article 2 of the Constitution, p. 221.

95 Gabr, The interpretation of Article 2 of the Constitution, p. 221. 
of the Sharia. In contrast, it classified the duration of guardianship as belonging to those subsidiary rules which were open to interpretation. Here, judges argued that as canonists had differed about the duration of guardianship while they "had all agreed that it should be determined according to what was in the best interest of the child"96 (italics added), the duration itself must not be fixed. Rather, judges argued, the matter of duration "needed to take into account changing circumstances", ${ }^{97}$ or, in Sanhuri's ${ }^{98}$ terms, the historical embeddedness and thus the modern requirements with a view to the child's best interests in this particular case.

This argument of the Court is interesting for a twofold reason: first, it only implicitly relies on Sanhuri without referencing him directly while putting emphasis, however, on the significance of the respective (historical) context of the case while referring second quite explicitly to the Sharia and three of its verses. Considering this approach, it might appear as if the direct engagement with Shari'a verses was chosen by the secularly-trained judges in order to ensure more acceptance for its decision among the more conservative Islamists groups. The Court, by relying on verses pertaining to the primary source per excellence, thereby reasserts that it is Sharia itself that allows - with regard to specific contexts - for "flexibility through its subsidiary rules which recognised the evolving nature of society." ${ }^{\prime 9}$ The Court underlined that interpretation was, however,

a difficult and sensitive task. The legislature when considering how to apply non-definite rules had to ensure that the fundamental Islamic legal guidelines were adhered to. In this instance Article 20, by respecting the interests of the child when determining the termination of guardianship had achieved this. Consequently, the allegation that the first paragraph of Article 20 of the Personal Status Law No 25 of 1929 as amended by Law No 100 of 1985 was unconstitutional was not well founded. ${ }^{100}$

With regard to Article 18 and its provisions in terms of alimony (motaa or mut'a) the Court asked whether the law under review (here Article 18 of Law 25 as amended by Law No 100 in 1985) was inconsistent with an absolutely certain ruling of the Sharia. Thus, in order to determine the constitutionality of

\footnotetext{
96 Gabr, The interpretation of Article 2 of the Constitution, p. 221.

97 Gabr, The interpretation of Article 2 of the Constitution, p. 221.

98 Beside Rashid Rida, Sanhuri can be considered one of the two main precursors of modernists that impacted the Court's reasoning.

99 Gabr, The interpretation of Article 2 of the Constitution, p. 221.

100 Gabr, The interpretation of Article 2 of the Constitution, p. 221.
} 
Article 18, the SCC raised the question "whether the legal provisions of Law No 100 governing compensation are inconsistent with any absolutely certain rulings of the shari'a."101 Interestingly, when searching for these rulings, the scc decided to not discuss the hadiths but rather discussed Qur'anic passages exclusively. In looking for absolutely certain legal rulings, the Court says, it was trying to identify rulings "rooted in principles laid down in Qur'anic nusus", 102 that is in Qur'anic texts that are absolutely clear and in which no ambiguities can be found. Ultimately, the Court identified three Qur'anic verses that it considered "relevant to the question of compensation for a divorced woman." 103

Considering the plaintiff's objection to his ex-wife's claim for mut'a, the SCC referenced God's pronouncement in Sura verse 241 (2:241) which reads that "[f]or divorced women it [mut'a] was a provision of kindness, a duty for the pious." ${ }^{104}$ Furthermore, scC's judges also cited Qur'an 2:236 which states that

men who marry women without promising any particular dowry, and then divorce them without consummating the marriage, must 'make provision for them [...] the affluent man according to his means, and according to his means the needy man - [This is] an obligation on those who [would] do good. ${ }^{105}$

Finally, the Court referred to a verse the classical jurists had not considered to be a verse of general application, but rather one "creating a ruling to solve a problem unique to the Prophet."106 This third Qur'anic passage can be found at Qur'an 33:29 and explicitly refers to the specific situation of the Prophet Muhammad when he was considering divorcing some of his wives. It reads "Oh Prophet, say to your wives 'If you desire the present life and its adornment, come now! I will make you a provision and set you free in kindness."'107 Given the specific context of the verse, the Court's use of it is surprising and it remains "unclear why the Court rejected the traditional, narrow interpretation

\footnotetext{
101 Lombardi, State Law as Islamic Law in Modern Egypt, p. 213.

102 Case No 7, Judicial Year 8 (May 15, 1993), 287 as cited in: Lombardi, State Law as Islamic Law in Modern Egypt, p. 213.

103 Lombardi, State Law as Islamic Law in Modern Egypt, p. 213.

104 The Cow Sura verse 241 as cited in: Gabr, The interpretation of Article 2 of the Constitution, p. 221. This verse was cited by the judges in Case 7, Judicial Year 8 (May 15, 1993), pp. 287288, as cited in: Lombardi, State Law as Islamic Law in Modern Egypt, p. 213.

105 Arabic cited in Case No 7, Judicial Year 8 (May 15, 1993), pp. 287-288, as cited in Lombardi, State Law as Islamic Law in Modern Egypt, p. 213.

106 Lombardi, State Law as Islamic Law in Modern Egypt, p. 214.

107 Lombardi, State Law as Islamic Law in Modern Egypt, p. 213.
} 
and instead reads it as a verse of general application."108 This is all the more striking as "authoritative hadith traditions make clear that this passage gave instructions designed to tell the Prophet how to deal with a unique problem which had arisen among his wives."109

Yet, this unexplained use of this latter verse by the Court suggests that scc's judges first, are not inclined to treat the hadiths as a source of general guidance and second, seem to be confident enough to radically re-interpret even those Qur'anic sources that are quite explicit about their originally much more narrow contexts. Therefore, in this particular case the Court creates the impression that it tends to rely only on those Sharia verses judges regarded as suitable to substantiate what they considered qualified primary sources with a view to adhering to the universal goals of the Shari'a as applied in modern contexts and in line with the Court's liberal interpretation.

In its opinion the Court (maybe in its attempt to appease disgruntled traditionalists) concedes that it was, indeed, "clear from the opinions of a number of canonists that there were different interpretations of the Qur'anic verses both in relation to the scope of the 'motaa's' application and as to whether it was compulsory or not."110 This, the Court argued, arose from the fact that God's Will in this matter was not definite. Consequently, the Court underlined that the role of the legislature was to draft legislation which defined the conditions of the right to receive alimony in such a manner that would "ensure consistent application without contradicting the fundamental principles of the Shari'a."111 (italics added) The scc continued that the legislation under review

provided two conditions for entitlement. Firstly, consummation of the marriage and secondly, that a divorce was without either the consent of the woman or was not of her making. Neither, in the Court's opinion, contradicted the Shari'a principles because the 'motaa' was intended to provide a remedy for the divorced woman for the harm caused to her. ${ }^{112}$ (italics added)

Thereby and to the consternation of the plaintiff, the scc "rejected the allegation of the husband that the 'motaa' provision was only available to women who had not consummated the marriage before divorce since God had ordered

\footnotetext{
108 Lombardi, State Law as Islamic Law in Modern Egypt, p. 214.

109 Lombardi, State Law as Islamic Law in Modern Egypt, p. 214.

110 Gabr, The interpretation of Article 2 of the Constitution, p. 222.

111 Gabr, The interpretation of Article 2 of the Constitution, p. 222.

112 Gabr, The interpretation of Article 2 of the Constitution, p. 222.
} 
that every divorced woman should receive a 'provision of kindness.'"113 (italics added)

In the end, the scc's judges argued that because the three verses referenced

were ambiguous, the Court found that there was no absolutely certain ruling precluding the state from requiring some compensation in addition to the dowry. Such a conclusion was conformed, the scc said, by the fact that the classical jurists disagreed about whether a man should be required to supplement his divorced wife's dowry with something extra. [...] Where there is no absolute certain ruling of the shari'a precisely on point, the wali al-amr [the ruler, or here the legislator] is free to develop whatever rule he thinks is best ${ }^{114}$

as long as this rule does not violate any of the constitutional principles including Article 2 and its human rights provisions.

To sum up this section, the following quote provides the English translation of the opinion of the Court in regard to the aspect of alimony:

It is clear from examining the doctrines of the jurists regarding the meaning of the Qur'anic texts [...] which have come to us in the matter of mut'a that they differ on the scope of their application and on whether it [...] is, on the one hand, obligatory, or, on the other hand, meritorious [but not required]. And this only means that since these texts are probable in meaning, they are unclear about the desire of God, may he be exalted. And thus the wali al-amr is permitted to practice ijtihad so as to develop a legislation [...] and to organize the shari'a's rules by establishing the essence of the right $[\ldots]$ in them. He [...] explicates its demands and unifies its application. He [...] establishes its edifice on a conception of equality with a view to removing all aspects of difference in it, and does not contradict the roots of the sharia, or any of its principles. [...] There is nothing in the Qur'anic texts informing us that God, [...], decreed it [a particular type or amount of $\left.m u t^{\prime} a\right]$ or set limits on it, inasmuch as they signify permission to organize it [...] so that he realizes for the people, their benefits stipulated by the sharia. ${ }^{115}$ (italics added)

113 Gabr, The interpretation of Article 2 of the Constitution, p. 222.

114 Lombardi, State Law as Islamic Law in Modern Egypt, p. 214.

115 Case No. 7 of Judicial Year 8 (May 15, 1993), p. 289. Cited in: Lombardi, State Law as Islamic Law in Modern Egypt, p. 215. 
By reading this paragraph of the Court's reasoning carefully, it becomes clear that the judges not only seem to suggest that a ruler's modern textualist approach of Sharia does indeed decrease the tension between Sharia and international human rights provisions. Rather, the judges even seem to argue that the need to enact state law that promotes social benefits, provisions of kindness and welfare for the people and thus, in modern terms, provisions that foster human rights law, can be drawn from certain Sharia verses directly. The following section on the Court's reasoning will stress this point further. That is, in the following section, I address the Court's reasoning and its according method in a more detailed fashion. Passages including judges' arguments in that Case were translated by Clark B. Lombardi from Arabic to English. The copy of the Case had been kindly provided by justice Adel Omar Sherif of the sCC. ${ }^{116}$

12 The Court's Reasoning

According to the Court

the principles of the Islamic sharia include two types: (1) the rulings of the sharia which are absolutely certain in their authenticity and meaning [...]; and (2) the principles requiring Muslims to act in a way that the scc, using its own interpretive method, determines to be 'goals' (specific or general) of the shari'a. ${ }^{117}$

At the beginning of its May 1993 opinion on Case No 7, the SCC underlined and thereby clarified that Article 2 of the Egyptian Constitution "commanded the government to respect (1) the rulings of the shari'a which established the moral quality of particular actions, and (2) the goals [or general universal principles and benefits] of the sharia."118 Lombardi's translation of the opening lines to the Court's first Article 2 opinion in Case No 7 of Judicial Year 8 reads as follows:

A legislative text is not permitted to contradict Islamic legal rulings that are absolutely certain in their authenticity and meaning [...]. It is these rulings alone in which ijtihad is not permitted. They represent the Islamic sharia, its universal principles and established roots which are

116 See Lombardi, State Law as Islamic Law in Modern Egypt, p. 202.

117 Lombardi, State Law as Islamic Law in Modern Egypt, p. 206.

118 Lombardi, State Law as Islamic Law in Modern Egypt, p. 18o. 
not subject to interpretation or alteration [...]; and it is inconceivable that the interpretation of them [the universally applicable principles] will change with a change of time and place [...] [It may only contravene] the rulings that are probable whether with respect to their authenticity or their meaning or both [...] The sphere of ijtihad is limited to them [the probable rulings of the sharia] [...] And they [the rulings that are merely probable] change with the change of times and place in order to guarantee their malleability and vigour in order to face new circumstances and in order to organize the affairs of the people, with respect to their welfare from the consideration of law [...] It is necessary that ijtihad occur within the frame of the universal roots of the Islamic sharia [...] building practical rulings and, in discovering them [these rulings], relying on the justice of the sharia [and] expecting the results of them [these rulings] to be a realization of the general goals of the sharia, among which are the protection of religion, life, reason, honour, and property. ${ }^{119}$ (italics added)

On the one hand, the Court's provision that rulings not open to ijtihad need to be absolutely certain as related to both their authenticity and meaning, clearly relies on Rashid Rida's precursory modernist theory. On the other hand, the SCC's emphasis on the "malleability and vigour in order to face new circumstances" reflects Sanhuri's stress on the historical embeddedness and the import to consider changes related to time and place when interpreting the merely probable provisions of the sacrosanct sources. Considering Case No 7 , Judicial Year 8 (May 15, 1993) the Court justified its re-interpretation of siyasa shari'yya with a particular view to societies' goals and benefits, God wanted it to enjoy. The translation reads as follows:

The Islamic shari'a in its universal principles - those that are absolutely clear $[\ldots]$ in their authenticity and their meaning [...] do not fix a limit beyond which the age of hadana cannot go. [...] [And to the extent that the legislature is not bound by any specific absolutely certain rulings] ijtihad must occur within the framework of the Islamic sharia's general roots [...] and [must] not go beyond them - by constructing practical rules by depending on deducing them from the indicators of the sharia and intending to realize through them the general goals of the sharia,

119 Case No. 7, Judicial Year 8 (May 15, 1993), pp. 283-285. Cited in: Lombardi, State Law as Islamic Law in Modern Egypt, p. 18 o. 
among which are the preservation of religion (din), self (nafs), reason ('aql), honor ('ird) and money (mal). ${ }^{120}$ (italics added)

Most strikingly, the SCC holds that the legislature is not bound by any specific rulings as contrasted to the general principles constituting universally absolutely certain rulings. Thereby, the Court provides for the legislature and for itself a broad margin of discretion.

\section{Conclusion}

The previous account has shown the wide range of Islamic law in its historical existence, and the equally broad variety of receptions of that tradition in highly fractured contemporary societies. My assumption that the application of Islamic law can - under very specific circumstances - serve liberal ends that are not in conflict with the implementation of human rights, has been substantiated by the discussion above with regard to Egypt during the 199os. However, in order to be able to make more far-reaching judgments about the compatibility of the application of Islamic law with the implementation of human rights, further research is needed. This research should involve - ideally from a comparative angle - the evaluation of the jurisdiction on human rights by various constitutional courts of different Islamic states, that is to say of those states that stipulate the predominance of Islamic law within their constitutions.

With this article, I aimed to reinforce my assumption that the interpretation and application of Islamic law can, in principle, serve liberal ends, but that this requires the confluence of highly contingent factors. That these factors came together in the Egypt of the 199os illustrates the contingency of Islamic law, ${ }^{121}$ but it should not blind us to the possibility of illiberal apologia. ${ }^{122}$

With a view to strengthening compliance with human rights standards through the progressive employment of the flexibility inherent in figh, judges of the sCC played an important and on balance successful role during the 199os. We have seen that they used references to Islamic law not only to underline the constitutional supremacy clause against an authoritarian executive. In addition, they sought to shore up popular support in a religiously conservative society by presenting international human rights standards as not only

120 Case No. 7, Judicial Year 8 (May 15, 1993), pp. 283-285. Cited in: Lombardi, State Law as Islamic Law in Modern Egypt, p. 207.

121 See also the different essays in Johansen, Contingency in a Sacred Law.

122 See for instance Euben, Premodern, Antimodern or Postmodern?, pp. 429-459. 
compatible with the strictures of religion but even as prescribed by Sharia itself as discussed above in the previous sections.

In sum, the SCC has not been very forthcoming with regard to the question which sources its judges considered certain with regard to both their authenticity related to first, transmission and second, the meaning of the sources. Neither have the judges been very communicative in setting forth according to which criteria these sources can be distinguished from other less certain reports, such as the hadiths, to name but one example for texts that the Court was extremely reluctant to reference.

I conclude that it is possible to tell a tale of a constitutional provision that had disingenuously been devised by an authoritarian executive to acquire popular legitimacy, suddenly being discovered by progressive, pragmatic and strategic judges of Egypt's SCC during the 199os, thereby acquiring a new lease on life at great cost to the executive. Counter-intuitively, liberal judges found the ancient methodology of $f i g h$ to be such a useful tool. In the 199os, the Court was savvy to use the precedent rise of powerful Islamist opposition movements which had embraced various re-conceptions of the doctrine of siyasa shari'yya and combined its own reading of social benefits to be extracted directly from Sharia law with a method of utilitarian neo-ijtihad under - at least implicit - reliance of modernist precursors such as Rashid Rida and Abd al-Razzaq Ahmad al Sanhuri. ${ }^{123}$ Amidst political stagnation and repression in Egypt, these new actors manifested a new type of political dynamism that tried to match Islamic thinking with compliance with human rights standards. In regard to further research, it would be interesting to investigate whether and if so, to what extent the SCC has been successful in following its liberal and pragmatic approach in the post-Mubarak era as well, or whether the 199os must be considered a rare exception.

\section{Biography}

Dr. Wiebke Greeff, born in 1984, studied Political Science and Legal Sociology at the Universities of Oldenburg, Frankfurt am Main, Virginia Tech and Manchester. She obtained a doctorate in law from the University of Manchester, UK in December 2018 with a thesis on "Positioning Egypt and the Islamic Republic of Iran on the international Rule of Law Scale. A post-Luhmannian approach". She is currently working at the Department for Research and

123 See on the Court's reference to Sanhuri and Rida: Lombardi, State Law as Islamic Law in Modern Egypt, Chapter 5 . 
Transfer at the Carl of Ossietzky University Oldenburg, where she works to improve career prospects for doctoral students. Her research interests include Legal Sociology, International Human Rights Law, the MENA region (particularly Egypt and Iran) and comparative Constitutional Law.

\section{Bibliography}

Abiad, Nisrine: Sharia, Muslim States and International Rights Treaty Obligations: A Comparative Study. London: British Institute of International Law and Comparative Law 2008.

Agrama, Hussein: Asking the Right Question. Two Engagements with Islam and Modernity (Review Essay), in: Political Theory 34 (5/2006), pp. 647-656.

Arjomand, Saïd Amir: Constitutions and the Struggle for Political Order: A Study in the Modernization of Political Traditions, in: European Journal of Sociology 33 (1/1992), pp. 39-82.

Bauer, Thomas: Die Kultur der Ambiguität. Eine andere Geschichte des Islam. Berlin: Verlag der Weltreligionen 2011.

Berger, Maurits/Sonneveld, Nadia: Sharia and National Law in Egypt, in: Jan Michiel Otto (ed.): Sharia Incorporated. A Comparative Overview of the Legal Systems of Twelve Muslim Countries in Past and Present. Dordrecht: Leiden University Press 2010, pp. 51-88.

Boyle, Kevin: Human Rights in Egypt: International Commitments, in: Kevin Boyle/ Adel Omar Sharif (eds.): Human Rights and Democracy. The Role of the Supreme Constitutional Court of Egypt. London: Kluwer Law International 1996, pp. 87-114.

Brown, Nathan J.: Constitutions in a Nonconstitutional World. Arab Basic Laws and the Prospects for Accountable Government. Albany: State University of New York Press 2002.

Brown, Nathan J.:Retrospective:Law and Imperialism:Egypt in Comparative Perspective, in: Law \& Society Review 29 (1/1995), pp. 103-125.

Burns, Jonathan G.: Introduction to Islamic Law: Principles of Civil, Criminal, and International Law under the Shari'a. USA: Teller Books 2013.

Cole, Juan: Napoleon's Egypt: Invading the Middle East. New York: Palgrave Macmillan 2007.

Constitute Project: Egypt's Constitution of 2014, https://www.constituteproject.org/ constitution/Egypt_2014.pdf (date of last access: 05.04.2021).

El Morr, Mohammed/Nossier, Abd El-Rahman/Sherif, Adel Omar: The Supreme Constitutional Court and its Role in the Egyptian Judicial System, in: Kevin Boyle/ Adel Omar Sherif (eds.): Human Rights and Democracy. The Role of the Supreme Constitutional Court of Egypt. London: Kluwer Law International 1996, pp. 13-36. 
Euben, Roxanne L.: Premodern, Antimodern or Postmodern? Islamic and Western Critiques of Modernity, in: Review of Politics 59 (3/1997), pp. 429-459.

Fahmy, Khaled: All the Pasha's Men: Mehmed Ali, His Army and the Making of Modern Egypt. Cairo: The American University in Cairo Press 2002.

Fukuyama, Francis: Foreword, in: Samuel P. Huntington (ed.): Political Order in Changing Societies. New Haven: Yale University Press New ed. 20o6, pp. xi-xvii.

Gabr, Hatem Aly Labib: The interpretation of Article 2 of the Constitution: Islamic Sharia Principles as a Source of Law, in: Kevin Boyle/Adel Omar Sherif (eds.): Human Rights and Democracy. The Role of the Supreme Constitutional Court of Egypt. London: Kluwer Law International ${ }^{1}$ 1996, pp. 217-227.

Hallaq, Wael B.: An Introduction to Islamic Law. Cambridge: Cambridge University Press 2009.

Hallaq, Wael B.: Sharīa: Theory, Practice, Transformations. Cambridge: Cambridge University Press 2009.

Hallaq, Wael B.: The Origins and Evolution of Islamic Law. Cambridge: Cambridge University Press 2005 .

Johansen, Baber: The Relationship Between the Constitution, the Sharîa and the Fiqh: The Jurisprudence of Egypt's Supreme Constitutional Court, in: Zeitschrift für ausländisches öffentliches Recht und Völkerrecht 64 (4/2004), pp. 881-896.

Johansen, Baber: The Muslim Fiqh as a Sacred Law: Religion, Law and Ethics in a Normative System, in: Baber Johanson (ed.): Contingency in a Sacred Law:Legal and Ethical Norms in the Muslim figh. Studies in Islamic Law and Society. Leiden: Brill 1999, pp. $1-77$.

Lohlker, Rüdiger: Islamisches Recht. Wien: facultas WUV - UTв 2012.

Lombardi, Clark B.: Egypt's Supreme Constitutional Court: Managing Constitutional Conflict in an Authoritarian, Aspirationally Islamic State, in:Journal of Comparative Law 3 (2/2008), pp. 234-253.

Lombardi, Clark B.: State Law as Islamic Law in Modern Egypt: The Incorporation of the Sharī‘a into Egyptian Constitutional Law. Leiden: Brill 2006.

Lombardi, Clark B.: Islamic Law as a Source of Constitutional Law in Egypt: The Constitutionalization of the Sharia in a Modern Arab State, in: The Columbia journal of transnational law 37 (1/1998), pp. 81-124.

Martin, Vanessa: Creating an Islamic State: Khomeini and the Making of a New Iran. London: I.B. Tauris New ed. 2003.

Moustafa, Tamir: The Struggle for Constitutional Power. Law, Politics, and Economic Development in Egypt. Cambridge: Cambridge University Press 2007.

Peters, Rudolph: The Islamization of Criminal Law: A Comparative Analysis, in: Die Welt des Islams 34 (2/1994), pp. 246-274.

Richmond, J.C.B.: Egypt, 1798-1952: Her Advance Towards a Modern Identity, Vol. 5. New York: Taylor \& Francis 2013. 
Rohe, Mathias: Das islamische Recht: Eine Einführung. München: C.H. Beck 2013.

Safran, Nadav: Abolition of the Shar'i Courts in Egypt, in: The Muslim World 48 (1/1958), p. 23 .

Salzman, Philip Carl: When They Proclaim "Islam is the Answer" What is the Question? The Return to Political Islam, in: Journal of the Middle East and Africa 2 (2/2011), pp. 129-152.

Schacht, Joseph: An Introduction to Islamic Law. Oxford: Oxford University Press ${ }^{1} 1964$.

Schacht, Joseph: The Schools of Law and Later Developments of Jurisprudence Chapter III, in: Majid Khadduri/Herbert J. Liebesny (eds.): Law in the Middle East, Vol. 1. Origin and Development of Islamic Law. Washington, DC: Middle East Institute 1955, pp. 57-84.

Sfeir, George N.: The Abolition of Confessional Jurisdiction in Egypt: The Non-Muslim Courts, in: Middle East Journal 10 (3/1956), pp. 248-256.

The Editors, Review Article on the UndP Arab Human Development Report: How the Arabs Compare, in: Middle East Quarterly IX (4/2002), pp. 59-67.

The Editors/Zaidam, Adam: Taqlïd, Islamic Law, http:// www.britannica.com/topic/ taqlid (date of last access: 04.04.2021).

Thompson, Elizabeth:Justice Interrupted. The Struggle for Constitutional Government in the Middle East. Cambridge, MA: Harvard University Press 2013.

Watt, W. Montgomery: Islamic Fundamentalism and Modernity. London: Routledge 1988. 